International Journal of Instruction e-ISSN: 1308-1470 • www.e-iji.net

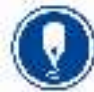

Article submission code: 20200521150323
Received: 21/05/2020

Revision: $14 / 10 / 2020$
April 2021 • Vol.14, No.2

p-ISSN: 1694-609X

pp. 703-718

Accepted: 06/11/2020

OnlineFirst: 21/02/2021

\title{
Male and Female University Students' Perceptions of an Effective EFL Teacher
}

\section{Rastislav Metruk}

Department of English Language and Literature, Faculty of Humanities, University of Žilina, Slovakia, rastislav.metruk@fhv.uniza.sk

Examining and understanding the concept of effective language instruction is of major significance as regards the process of teaching and learning foreign languages. This study attempts to investigate the differences in the male and female EFL (English as a foreign language) students' perceptions of effective language teachers. The convenient sampling technique, followed by the stratified sampling, was applied to gather the data from 25 males and 58 females $(n=83)$. First, ten highest-mean and ten lowest-mean items were analysed to investigate the most important and the least important qualities of an effective language teacher. Afterwards, 57 independent-sample t-tests were carried out in order to find and recognize the potential differences between the particular questionnaire items as perceived by the male and female participants. The research outcomes demonstrate that the differences between the perception of the highest-mean and lowest-mean items are not considerable between the two sexes despite some detected variances. Furthermore, the statistically significant differences $(p \leq 0.05)$ were observed in only 9 cases out of the 57 items, which means that overall, the differences are not substantial, and the male and female students generally tend to agree on the characteristics of an effective language teacher.

Keywords: effective language teacher, EFL student, teaching English, perception, gender

\section{INTRODUCTION}

Learning a language represents a challenging and complex process of mastering language systems and skills (Brković, Kardum, \& Togonal, 2021; Hundarenko, 2019; Kapranov, 2019; Mulyadi, Arifani, Wijayantingsih \& Budiastuti, 2020; Sides \& Cuevas 2020; Stognieva, 2020; Štubňa, 2019). Undeniably, language teachers occupy a substantial role in delivering success to language teaching environments (Başal, 2014; Tuncel \& Çobanoğlu, 2018). Foreign language students and teachers may have rather similar or different attitudes towards effective language teaching, and the intersection of the two sets has implications for language learning and the effectivity of teaching (Moradi \& Sabeti, 2014). "This discrepancy between these two groups' opinions might lead to some unanticipated mismatches in the actual practice of language teaching,

Citation: Metruk, R. (2021). Male and Female University Students' Perceptions of an Effective EFL Teacher. International Journal of Instruction, 14(2), 703-718. https://doi.org/10.29333/iji.2021.14239a 
which might, in turn, result in either students' dissatisfaction or less than satisfactory learning outcomes" (Alimorad \& Tajgozari, 2016, 1). Therefore, uncovering the perceptions of effective language teaching can be beneficial to both students and teaches.

Given the fact that the perceptions can be regarded as dynamic and flexible (Brown, 2009), constant research performed from different perspectives may stimulate teachers' opinions on the practices of effective language teaching. As far as gender is concerned, Alimorad and Tajgozari (2016) explain that "the role of teachers' and students' gender is studied to see whether their gender can be considered as a determining factor influencing their perceptions". It is also Zadeh (2016) who indicates that further studies can be performed concerning differences between the male and female students' perception of effective teachers. Moreover, the gender factors ought to be taken into consideration within their perceptions. It may be, therefore, suggested that due to the fact that there may be discrepancies in understanding the effective language teaching as regards the two sexes, conducting further studies in this area may shed more light on this matter and provide researchers and educators with a broader picture in terms of learners' perceptions of effective teaching.

The concept of an effective language teacher has been examined by numerous scholars in the past decades and this issue has been approached from various angles. Hativa, Barak, and Simhi (2001) suggest that teachers' effectiveness is not restricted only to their characteristics or merely adhering to a particular set of criteria; it also concerns applying practices which contribute towards a wider community within which teaching is realized. Brosh (1996) maintains that effective EFL teachers are the ones who concentrate on comprehension, are in command of the language, hold interesting lessons, aid learners with being independent, and treat them fairly. Vadillio (1999) adds to the discussion by claiming that the effective language educators are those who not only possess a profound competence in L2, but also personal features such as sensitivity, warmth, and tolerance.

According to Sotto (2011), a good teacher is someone who encourages learners to be more confident and thoughtful, which can be achieved through engaging them in numerous experiences which support their development. On the other hand, Bell (2005) points out that an effective EFL teacher usually employs communicative approaches, uses small group for discussions, and employ effective strategies within their teaching. In a similar way, Al-Maqtri and Thabet (2013) explain that EFL teachers ought to have a good mastery of English (including the phonological system) and their students should be more actively involved in classroom activities.

On the basis of what has already been mentioned and given the fact that different authors may have different views on what the qualities of an effective language practitioner are, this area of language teaching merits further investigation of educators and researchers in order to provide instructors with necessary information regarding the implementation of language teacher development programmes (Çelik, Arikan \& Caner, 2013). Examining the qualities of good and effective teachers is of vital importance and may thus prove beneficial to both teachers and learners. 
This research attempts to contribute towards the existing knowledge by examining the differences in male and female learners' perceptions of good and effective language teachers in the context of Slovak university EFL teaching. In order to achieve the objectives of this study, the following research questions were formulated:

1. What are the most important qualities of an effective EFL teacher as perceived by male and female students? What are the differences between the two sexes?

2. What are the least important qualities of an effective EFL teacher as perceived by male and female students? What are the differences between the two sexes?

3. What are the differences between the overall male and female's perception of an effective EFL teacher?

\section{LITERATURE REVIEW}

\section{Perception of effective language instruction}

Numerous scholars and researchers attempted to cast new light on the matter of effective language teaching predominantly from two viewpoints: learners' point of view (e.g. Çakmak \& Gündüz, 2018; Demiroz \& Yesilyurt, 2015; Ghasemi \& Hashemi, 2011; Kourieos \& Evripidou, 2013; Lee, 2010; Sabbah, 2018; Sandholtz, 2011) and both teachers and learners' standpoints - comparing the two sets of opinions in order to uncover the potential differences between the two groups (e.g. Al-Mahrooqi, Denman, Al-Siyabi \& Al-Maamari, 2015; Alimorad \& Tajgozari 2016; Brown, 2009; Katooli \& Abdolmanafi-Rokni, 2015; Park \& Lee, 2006; Shishavan \& Sadeghi, 2009; Tok, 2010).

The literature background suggests that in some instances, there are differences between teachers' and learners' opinions and sometimes, there are not. Moreover, the differences are not always of the same nature.

For example, the study by Park and Lee (2006) revealed that there exist considerable differences between the perception of effective language teachers between the teachers' and students' viewpoints. While the instructors considered English proficiency as most important, the students regarded the pedagogical knowledge the highest. Other study by Alimorad and Tajgozari (2016) also supports the notion that perceptions of learners differ substantially from their teachers' insights. While the instructors were in favour of a more traditional approach, their students preferred a more communicative approach. Further studies that exhibit significant differences between the instructors' and learners' perceptions of effective language teaching involve Katooli and Abdolmanafi-Rokni (2015), Ramazani (2014), or Tok (2010).

There are, however, also studies which display general agreement between teachers' and students' attitudes on effective language teaching. The outcomes of the study conducted by Al-Mahrooqi, Denman, Al-Siyabi and Al-Maamari (2015) demonstrate that the two groups generally agree on the importance of the characteristic categories, attaching particular significance to English proficiency and equal treatment of all students. Similarly, Shishavan and Sadeghi (2009) also revealed that the students' responses differed from those of their teachers' in only eight cases out of the 48 instances. Correspondingly, the study performed by Alzobiani (2020) also suggested that no statistically significant differences exist between the students' and teachers' perceptions 
of effective teachers. It can be argued that the research results in this field remain inconclusive and that further examination of teacher effectiveness needs to be carried out.

\section{Male and female perception of effective language instruction}

Several studies also attempted to explore the differences between male and female students regarding effective language teachers.

The study of AlTameemy (2019, p. 1180), which aimed at investigating students' attitudes towards effective instruction at Prince Sattam Bin Abdulaziz University, revealed that "the differences in perceptions about effective English language teaching qualities are not statistically significant as for the gender variable for all the participants in general". In a similar way, the paper by Al-Maqtri and Ahmad (2013) concentrated on the qualities of a good English teacher as perceived by Yemeni and Saudi college students of English. The study concludes that although female students showed more tendency towards teachers with better pronunciation than males, as far as gender was concerned, no major differences were found. Other studies which did not detect statistically significant differences between the male and female opinions towards the qualities of good and effective teachers include Zamani and Ahangari (2015), Wichadee (2010), and Zadeh (2016).

On the other hand, Park and Lee (2006) tried to examine the characteristics of effective EFL teachers as perceived by Korean teachers and students through a self-report questionnaire, comprising three categories - English proficiency, pedagogical knowledge, and socio-affective skills. The male students exhibited significant differences from their female counterparts in the socio-affective skills category. Moreover, "the male students reported having a good sense of humour as important to teaching more than the female students did, whereas the female students reported pronunciation proficiency, teaching how to learn English, and treating students fairly as important teacher characteristics" (Park \& Lee, 2006, p. 246). The authors further maintain that the relationship between the students' and teachers' perceptions concerning effective English teachers needs to be further explored. Correspondingly, Ghasemi and Hashemi's study (2011) also showed that it was the male students who displayed different characteristics from their female peers with regard to the socioaffective skills.

Chen and Lin (2009) investigated the matter of effective EFL teachers from the viewpoint of junior high school students in Tainan. The research results implied that the female students regarded the features of personality and teacher-student relationship considerably more important than their male counterparts. Furthermore, the females rated considerably higher on qualities such as motivating students to learn English and feeling familiar with the English culture, while the males considered respecting students and being ethical to be more important qualities for effective English teachers.

Benzehaf (2018) tried to explore university students' perceptions of characteristics of a good university teacher of English in Morocco. The findings suggest that both males and females deemed the subject matter knowledge to be the most important of teacher 
characteristics, but gender differences were recognized as regards the traits of effective teachers.

Arising out of the literature review, further investigation in this field is necessary to conduct to throw more light on this matter, especially in the context of Slovak EFL language teaching and learning, where the research in this field is scarce.

\section{METHOD}

\section{Research background}

This research concentrated on the qualities of an effective EFL teacher as perceived by Slovak university EFL students. The questionnaire was used as a primary research method and the research was quantitative in its nature. After the data were collected, they were statistically analysed and interpreted. The following research questions were designed in an attempt to accomplish the research objectives.

1. What are the most important qualities of an effective EFL teacher as perceived by male and female students? What are the differences between the two sexes?

2. What are the least important qualities of an effective EFL teacher as perceived by male and female students? What are the differences between the two sexes?

3. What are the differences between the overall male and female's perception of an effective EFL teacher?

\section{Sampling}

The research sample comprised Slovak university EFL learners, majoring in Teacher Training of English Language and Literature at a Slovak university. A total of 83 students, 25 males and 58 females (convenience sampling $\rightarrow$ stratified sampling), took part in this research. On average, the male students were 22.3 years of age and the females were 21.5 years old. Their level of English ranged from the B2 to C1 CEFR (Common European Framework of Reference for Languages) levels. Confidentiality as well as the voluntary nature of the participation was ensured. Furthermore, the participants were reassured that their responses would remain confidential and that they would never experience any problems because of taking part in this study.

\section{Research instrument and data analysis}

A 4-point Likert-type scale questionnaire (Appendix 1) was used to measure the respondents' perceptions of effective language teachers. It was prepared by Metruk (2020), who completed extensive review of existing questionnaires intended to measure the same concept by Al-Mahrooqi, Denman and Al-Siyabi (2015), Moradi and Sabeti (2014), and Shishavan and Sadeghi (2009). This research instrument had been revised three times, using help of author's colleagues and peers, which resulted in deleting 4 items (these seemed to somehow duplicate other statements) and reformulating 7 statements (to make them clearer to the respondents) when compared to its initial version. The final version consisted of altogether 57 items which focused on the characteristics of an effective teacher. In order to ensure the reliability of the questionnaire, the internal consistency of items, employing the Cronbach's Alpha formula, was calculated at 0.94 as regards the male questionnaire and 0.93 within the 
female questionnaire. "Cronbach's alpha reliability coefficient normally ranges between 0 and 1 . However, there is actually no lower limit to the coefficient. The closer Cronbach's alpha coefficient is to 1.0 the greater the internal consistency of the items in the scale" (Gliem \& Gliem, 2003, p. 87). Thus, the questionnaire can be considered reliable for the purposes of this research.

The research instrument was distributed via Google Forms to both male and female students. The respondents were asked to choose one of the four options $(1=$ unimportant quality of an effective teacher, $2=$ slightly important quality of an effective teacher, 3 = moderately important quality of an effective teacher, $4=$ very important quality of an effective teacher). The students were required to express their personal perception of effective teaching and they were informed that there were no right or wrong answers and that the right answer is the one that is right for them (based on what their opinion is).

\section{Data analysis}

57 independent-sample t-tests were conducted so as to make a comparison between the male and female students' perceptions of an effective teacher, which means that each questionnaire item has been statistically analysed as regards the potential gender differences in the perceptions. According to Auerbach and Zeitlin (2014), the p value in social sciences is normally set at $0.05(\mathrm{p} \leq 0.05)$, which means that the items that were lower than or equal to 0.05 can be regarded as statistically significant. These items along with their statistical interpretation can be found in the results section.

\section{FINDINGS AND DISCUSSION}

\section{The most important qualities of an effective EFL teacher}

The first research question is concerned with ten highest-ranked qualities of an effective teacher as perceived by the male and female students. Table 1 shows that five of the ten characteristics overlap (items no. 2, 3, 25, 33, 50). Thus, both groups think that an effective language teacher needs to be able to present content in a meaningful way, speak audibly and clearly, providing clear instructions. Moreover, the teacher should be fair and correct, having good communication skills.

The remaining five characteristics of an effective teacher differ. The male students assign the highest importance to an instructor who actively listens to students' opinions and lets them express themselves, not losing temper and getting angry, being confident and having self-control. Apart from that, effective teachers need to have a high level of English proficiency and they should afford opportunities to use English through meaningful tasks and activities.

On the other hand, the female students think that effective teachers should be polite and respect the personality of students, arouse learners' motivation, be knowledgeable, creative - using various methods and techniques, and build positive relationships with students, retaining a professional distance.

These findings suggest that although some differences in the ten highest-rated qualities can be observed, the variations do not appear to be substantial. Five of the ten items are 
identical for both groups and most of the remaining five items, apart from the male item 34 (having a high level of English proficiency) and the female item 19 (having good communication skills.), share some similarities such as personality features, teachers' traits, or teacher's language proficiency.

Table 1

Items with the highest means for male and female students

\begin{tabular}{|c|c|c|c|c|c|}
\hline \multicolumn{3}{|c|}{ Male students } & \multicolumn{3}{|c|}{ Female students } \\
\hline $\begin{array}{l}\text { Item } \\
\text { no. }\end{array}$ & Item & Mean & $\begin{array}{l}\text { Item } \\
\text { no. }\end{array}$ & Item & Mean \\
\hline 3 & $\begin{array}{l}\text { Be able to present content to } \\
\text { students in a meaningful way. }\end{array}$ & 3.84 & 2 & $\begin{array}{l}\text { Be able to provide clear } \\
\text { instructions for tasks. }\end{array}$ & 3.88 \\
\hline 50 & Speak audibly and clearly. & 3.72 & 25 & $\begin{array}{l}\text { Be fair and correct (within } \\
\text { feedback, giving turns, attending } \\
\text { to individual differences). }\end{array}$ & 3.86 \\
\hline 2 & $\begin{array}{l}\text { Be able to provide clear } \\
\text { instructions for tasks. }\end{array}$ & 3.68 & 3 & $\begin{array}{l}\text { Be able to present content to } \\
\text { students in a meaningful way }\end{array}$ & 3.83 \\
\hline 21 & $\begin{array}{l}\text { Actively listen to student's } \\
\text { opinions and let them express } \\
\text { themselves. }\end{array}$ & 3.68 & 37 & $\begin{array}{l}\text { Be polite and respect the } \\
\text { personality of students. }\end{array}$ & 3.81 \\
\hline 25 & $\begin{array}{l}\text { Be fair and correct (within } \\
\text { feedback, giving turns, attending } \\
\text { to individual differences). }\end{array}$ & 3.64 & 50 & Speak audibly and clearly. & 3.79 \\
\hline 38 & Not lose temper and get angry. & 3.64 & 16 & $\begin{array}{l}\text { Arouse students' motivation for } \\
\text { learning English. }\end{array}$ & 3.72 \\
\hline 54 & $\begin{array}{l}\text { Be confident and have self- } \\
\text { control. }\end{array}$ & 3.64 & 27 & $\begin{array}{l}\text { Be knowledgeable } \\
\text { (have the subject matter } \\
\text { knowledge and have the } \\
\text { pedagogical knowledge). }\end{array}$ & 3.72 \\
\hline 33 & Have good communication skills. & 3.60 & 19 & $\begin{array}{l}\text { Be creative; use various methods } \\
\text { and techniques in teaching. }\end{array}$ & 3.69 \\
\hline 34 & $\begin{array}{l}\text { Have a high level of English } \\
\text { proficiency. }\end{array}$ & 3.60 & 33 & Have good communication skills. & 3.69 \\
\hline 6 & $\begin{array}{l}\text { Provide opportunities to use } \\
\text { English through meaningful } \\
\text { tasks and activities. }\end{array}$ & 3.56 & 36 & $\begin{array}{l}\text { Build a positive relationship } \\
\text { with students but focus on } \\
\text { retaining a professional distance. }\end{array}$ & 3.69 \\
\hline
\end{tabular}

\section{The least important qualities of an effective language teacher}

The second research question is concerned with ten lowest-mean items. Table 2 reveals that as many as seven out of the ten items (items no. 10, 14, 23, 29, 42, 43, 48) are identical for both groups. The remaining three items somewhat differ.

While the males consider being on time and finishing on time, giving reasonable amount of homework, and diagnosing learners' learning problems to be also of low importance, the females are more concerned with items that are slightly more related to actual language teaching (rather than) personality or traits of a teacher. The female students attach low importance to teachers having a university degree in teaching languages, being aware of current teaching techniques and finally, being up-to-date.

Overall, the differences in the male and female students' perception of the lowest-ranked qualities are not considerable, as both sexes agreed on most of the items. 
Table 2

Items with the lowest means for male and female students

\begin{tabular}{|c|c|c|c|c|c|}
\hline \multicolumn{3}{|c|}{ Male students } & \multicolumn{3}{|c|}{ Female students } \\
\hline $\begin{array}{l}\text { Item } \\
\text { no. }\end{array}$ & Item & Mean & $\begin{array}{l}\text { Item } \\
\text { no. }\end{array}$ & Item & Mean \\
\hline 29 & Be neat and tidy in appearance. & 2.40 & 42 & $\begin{array}{l}\text { Have more than five years' } \\
\text { experience of English teaching. }\end{array}$ & 2.26 \\
\hline 42 & $\begin{array}{l}\text { Have more than five years' } \\
\text { experience of English teaching. }\end{array}$ & 2.44 & 43 & $\begin{array}{l}\text { Be familiar with the social and } \\
\text { cultural background of learners. }\end{array}$ & 2.52 \\
\hline 48 & $\begin{array}{l}\text { Vary class interaction strategies } \\
\text { (e.g. use group and pair work, } \\
\text { drama, role-plays, debates, etc.). }\end{array}$ & 2.68 & 29 & Be neat and tidy in appearance. & 2.71 \\
\hline 14 & $\begin{array}{l}\text { Employ plenty of pair work and } \\
\text { group work in which his/her } \\
\text { learners can practice English. }\end{array}$ & 2.76 & 14 & $\begin{array}{l}\text { Employ plenty of pair work and } \\
\text { group work in which his/her } \\
\text { learners can practice English. }\end{array}$ & 2.97 \\
\hline 10 & Know English culture well & 2.80 & 23 & $\begin{array}{l}\text { Support the notion that fluency } \\
\text { is somewhat more important } \\
\text { than accuracy. }\end{array}$ & 2.97 \\
\hline 52 & $\begin{array}{l}\text { Come to class on time and finish } \\
\text { on time }\end{array}$ & 2.80 & 10 & Know English culture well. & 2.98 \\
\hline 5 & $\begin{array}{l}\text { Give a reasonable amount of } \\
\text { homework/home assignments. }\end{array}$ & 2.84 & 44 & $\begin{array}{l}\text { Be aware of the current teaching } \\
\text { techniques. }\end{array}$ & 3.03 \\
\hline 43 & $\begin{array}{l}\text { Be familiar with the social and } \\
\text { cultural background of learners }\end{array}$ & 2.84 & 48 & $\begin{array}{l}\text { Vary class interaction strategies } \\
\text { (e.g. use group and pair work, } \\
\text { drama, role-plays, debates, etc.) }\end{array}$ & 3.05 \\
\hline 17 & $\begin{array}{l}\text { Diagnose learners' learning } \\
\text { problems. }\end{array}$ & 2.92 & 41 & $\begin{array}{l}\text { Have a university degree in } \\
\text { Teaching English as a Foreign } \\
\text { Language. }\end{array}$ & 3.07 \\
\hline 23 & $\begin{array}{l}\text { Support the notion that fluency is } \\
\text { somewhat more important than } \\
\text { accuracy. }\end{array}$ & 2.92 & 8 & $\begin{array}{l}\text { Be up-to-date (e.g. use the } \\
\text { Internet and recent technologies } \\
\text { in teaching). }\end{array}$ & 3.09 \\
\hline
\end{tabular}

\section{Differences between the male and female perceptions}

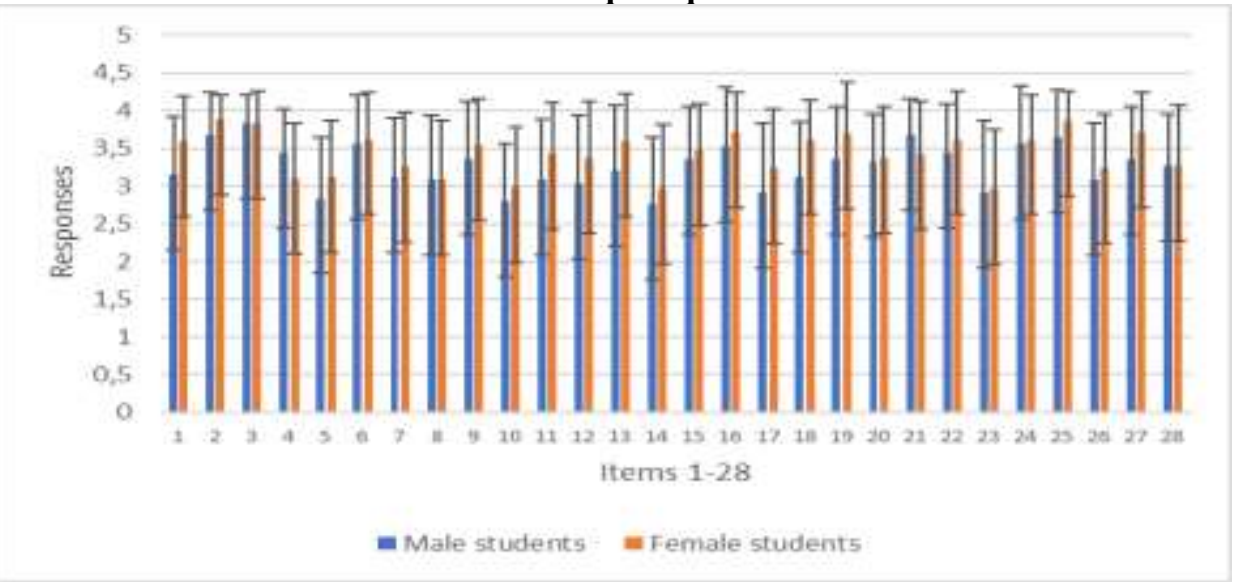

Figure 1

Means and standard deviations for items 1-28 


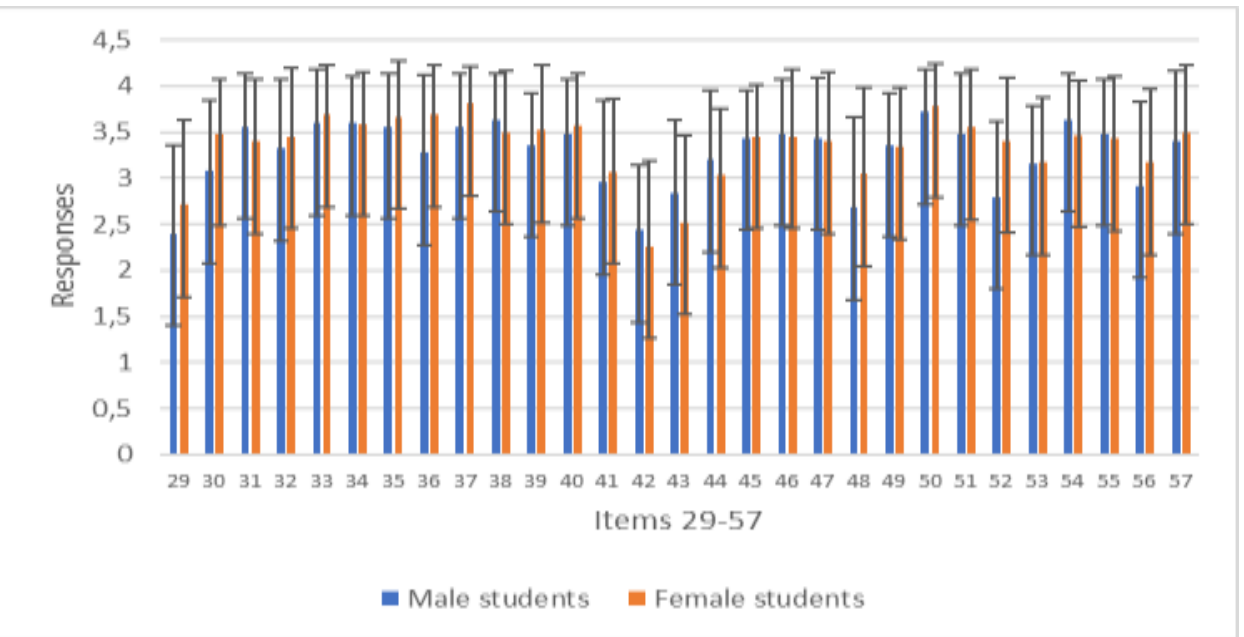

Figure 2

Means and standard deviations for items 29-57

The third research question focused on the potential differences as regards gender perception of an effective language teacher. Thus, 57 independent-sample t-tests were run in order to examine whether the differences between all questionnaire items are statistically significant or not. Figures 1 and 2 show the mean values and standard deviations for both genders and the statistically significant questionnaire items $(\mathrm{p} \leq$ $0.05)$ are displayed in Table 3.

Table 3

Statistically significant items $(\mathrm{p} \leq 0.05)$

\begin{tabular}{|c|c|c|c|c|c|c|}
\hline \multirow[b]{2}{*}{ No. } & \multirow{2}{*}{$\begin{array}{l}\text { Item } \\
\text { A good and effective EFL teacher is someone } \\
\text { who should: }\end{array}$} & \multicolumn{2}{|c|}{ Male students } & \multicolumn{2}{|c|}{ Female students } & \multirow[b]{2}{*}{$\begin{array}{l}p \\
\text { value }\end{array}$} \\
\hline & & Mean & SD & Mean & SD & \\
\hline 1. & Be well prepared for each lesson. & 3.16 & 0.75 & 3.60 & 0.59 & 0.01 \\
\hline 4. & $\begin{array}{l}\text { Personalize his/her teaching to students' lives, } \\
\text { needs, concerns, goals, and interests }\end{array}$ & 3.44 & 0.58 & 3.10 & 0.74 & 0.03 \\
\hline 13. & $\begin{array}{l}\text { Be upbeat (positive and enthusiastic; making } \\
\text { you feel that the future will be good). }\end{array}$ & 3.20 & 0.87 & 3.60 & 0.62 & 0.04 \\
\hline 18. & $\begin{array}{l}\text { Manage the class time well and use the time } \\
\text { efficiently. }\end{array}$ & 3.12 & 0.73 & 3.62 & 0.52 & 0,00 \\
\hline 19. & $\begin{array}{l}\text { Be creative; use various methods and } \\
\text { techniques in teaching. }\end{array}$ & 3.36 & 0.70 & 3.69 & 0.68 & 0.05 \\
\hline 27. & $\begin{array}{l}\text { Be knowledgeable (have the subject matter } \\
\text { knowledge and have the pedagogical } \\
\text { knowledge). }\end{array}$ & 3.36 & 0.70 & 3.72 & 0.52 & 0.03 \\
\hline 30. & Be available for students. & 3.08 & 0.76 & 3.48 & 0.60 & 0.02 \\
\hline 36. & $\begin{array}{l}\text { Build a positive relationship with students } \\
\text { but focus on retaining a professional distance. }\end{array}$ & 3.28 & 0.84 & 3.69 & 0.54 & 0.03 \\
\hline 52. & Come to class on time and finish on time. & 2.80 & 0.82 & 3.41 & 0.68 & 0.00 \\
\hline
\end{tabular}




\section{Overall male and female perception of an effective EFL teacher}

Only 9 out of the total of 57 items were statistically significant as regards the perception of effective language teaching. The male students attached greater importance to effective teachers who personalize their teaching to learners' needs, concerns, goals, and interests, while the rest of the items were regarded as more important by the female students. Statistically greater significance is placed on the following features by the female group of participants - an effective language teacher is someone who should:

- be well prepared for each lesson;

- be upbeat;

- manage class time well and use it efficiently;

- be creative;

- be knowledgeable;

- be available for students;

- build positive relationship with students (focusing on retaining professional distance);

- come to class on time and finish on time.

It should be noted that most of the items refer to classroom management and personality features rather than to "actual" language teaching. Thus, it can be concluded that some differences in the males and females' perception of effective language teachers were detected, but only in 9 cases, which do not seem to be "directly linked" with actual teaching such as giving instructions, providing learners with feedback, pre-teaching vocabulary before listening, and the like.

On the whole, it has been observed that the differences between the two sexes are not of major significance; this study, therefore, approximates to the study of AlTameemy (2019), which also did not detect statistically significant differences in the perception of effective teaching qualities. Similarly, the study of Al-Maqtri and Ahmad (2013), suggesting that although the females tended to prefer educators with better pronunciation, no considerable differences were found, is also line with the research results of this paper. The findings of the research carried out by Wichadee (2010) or Zamani and Ahangari (2015) also correspond with our outcomes; despite the fact that the overall average score of females in their studies was slightly higher than that of males, no significant differences between the perceptions were found.

\section{CONCLUSION}

This paper sought to investigate the differences in the male and female perception of an effective language teacher by exploring the differences in ten highest-mean items, lowest-mean items, and all the items altogether.

Ten highest-mean and lowest-mean items revealed that 5 out of the 10 highest-mean items and 7 out of the 10 lowest-mean items (Table 1 and Table 2) were identical for both groups. Some of the remaining questionnaire statements which were not the same shared certain similarities; therefore, it can be concluded that although there exists some 
variation in the responses which were not identical for the both groups, there are no substantial differences overall in the perceptions of the highest-mean and lowest-mean items by the male and female students as regards effective language teaching.

Taking all 57 statements into account, the statistically significant differences were detected in only 9 instances (Table 3 ), which are somehow "indirectly linked" to the actual teaching as they were predominantly concerned with classroom management or teachers' attitudes towards teaching. Thus, despite the fact that the statistically significant differences were recognized within 9 statements, on the whole, the differences between the males' and females' perceptions do not appear to be considerable due to the fact that no statistically significant difference was observed within $84 \%$ of questionnaire statements. Overall, both male and female students tend to agree on the qualities of effective language teachers.

As with any study, there exist some limitations which arise out of the research design and employed methods. First, a convenience sampling with the subsequent stratified sampling was employed for both examined groups. Second, the research findings are based on a relatively small sample size. Future research should therefore involve more learners studying at university study programs aimed at preparing prospective EFL teachers, which could increase the generalizability of findings - a larger research sample would increase the reliability of the obtained data. Finally, implementing other research methods (apart from the questionnaire) such as in-depth interviews or observations may also prove useful.

As always, further research in this field is needed since the potential discrepancies between the male and female perceptions of effective language teaching may lead to some "unanticipated mismatches" in the practice of English language teaching.

\section{REFERENCES}

Al-Mahrooqi, R., Denman, C., Al-Siyabi, J., \& Al-Maamari, F. (2015). Characteristics of a Good EFL Teacher: Omani EFL Teacher and Student Perspectives. SAGE Open, 5(2), 1-15. https://doi.org/10.1177/2158244015584782

Al-Maqtri, M., \& Thabet, A. (2013). The Qualities of the Good English Teacher as Perceived by Saudi and Yemeni College Students of English. Greener Journal of Educational Research, 3(2), 72-79. Retrieved 18 May, 2020 from https://zenodo.org/record/3476927\#.XsK0EWgzaM8

Alimorad, Z., \& Tajgozari, M. (2016). A Comparison of Iranian High School Teachers' and Students' Perceptions of Effective English Teachers. SAGE Open, 6(4), 1-10. https://doi.org/10.1177/2158244016679212

AlTameemy, F. (2019). A Comparative Study of Teachers' and Students' Perceptions of the Effective English Teacher at Prince Sattam Bin Abdulaziz University. International Journal of Innovation, Creativity and Change, 5(2), 1168-1194. Retrieved 18 May, 2020 from https://www.ijicc.net/images/Vol5iss2_/69_AlTameemy_P1168_2019R.pdf 
Alzobiani, I. (2020). The Qualities of Effective Teachers as Perceived by Saudi EFL Students and Teachers. English Language Teaching, 13(2), 32-47. https://doi.org/10.5539/elt.v13n2p32

Auerbach, C., \& Zeitlin, W. (2014). SSD for R: An R Package for Analyzing SingleSubject Data. Oxford: UK, Oxford University Press

Başal, A. (2014). ICT in Language Teacher Education: The Role of Teacher Educators. In Pixel (Ed.) Conference Proceedings - ICT for Language Learning, 13-14 November 2014. Padova: Webster srl, pp. 222-225.

Bell, T. (2005). Behaviors and Attitudes of Effective Foreign Language Teachers: Results of a Questionnaire Study. Foreign Language Annals, 38, 259-270. https://doi.org/10.1111/j.1944-9720.2005.tb02490.x

Benzehaf, B. (2018). Teaching Excellence in Higher Education in Morocco: English Students' Perceptions of Teaching Effectiveness. Journal of Applied Language and Culture Studies, 1, 25-41. Retrieved 18 May, 2020 from https://revues.imist.ma/index.php?journal=JALCS\&page=article\&op=view\&path $\% 5 \mathrm{~B} \%$ $5 \mathrm{D}=13160 \&$ path $\% 5 \mathrm{~B} \% 5 \mathrm{D}=7320$

Brković, V., Kardum, R. B., \& Togonal, M. (2021). Language Competences in the Contemporary Teaching of History as a Prerequisite for a Successful Teaching Process. International Journal of Instruction, 14(1), 427-444. https://doi.org/10.29333/iji.2021.14125a

Brosh, H. (1996). Perceived Characteristics of the Effective Language Teacher. Foreign Language Annals, 29, 125-138. https://doi.org/10.1111/j.1944-9720.1996.tb02322.x

Brown, A. (2009). Students' and Teachers' Perceptions of Effective Foreign Language Teaching: A Comparison of Ideals. The Modern Language Journal, 93(1), 46-60. https://doi.org/10.1111/j.1540-4781.2009.00827.x

Çakmak, M., \& Gündüz, M. (2018). Pre-service ELT Teachers' Perceptions of Characteristics of Effective Teachers. Gazi University Journal of Gazi Educational Faculty, 38(1), 359-383. Retrieved 18 May, 2020 from http://static.dergipark.org.tr/article-download/1402/a287/b2f5/5adf2d045633f.pdf?

Çelik, S., Arikan, A., \& Caner, M. (2013). In the Eyes of Turkish EFL Learners: What Makes an Effective Foreign Language Teacher? Porta Linguarum 20, 287-297.

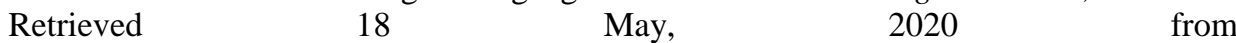
http://www.ugr.es/ portalin/articulos/PL_numero20/18\%20Servet\%20Celik.pdf

Chen, Y., \& Lin, S. (2009). Exploring Characteristics for Effective EFL Teachers From the Perceptions of Junior High School Students in Tainan. STUT Journal of Humanities and Social Sciences, 2, 219-249.

Council of Europe. (2001). Common European Framework of Reference for Languages: Learning, Teaching, Assessment. Cambridge, UK: Press Syndicate of the University of Cambridge 
Demiroz, H., \& Yesilyurt, S. (2015). Effective Foreign Language Teaching: Perceptions of Prospective English Language Teachers. Universal Journal of Educational Research 3(11), 862-870. https://doi.org/10.13189/ujer.2015.031112

Ghasemi, B., \& Hashemi, M. (2011). The Study of the Characteristics of Successful English Language Teachers from the View Point of the English Language Students of Islamic Azad University, Hamedan Branch. Procedia - Social and Behavioral Sciences, 28, 411-415. https://doi.org/10.1016/j.sbspro.2011.11.078

Gliem, J., \& Gliem, R. (2003). Calculating, Interpreting, And Reporting Cronbach's Alpha Reliability Coefficient For Likert-Type Scales. Midwest Research-to-Practice Conference in Adult, Continuing, and Community Education. Retrieved 19 May, 2020 from

https://scholarworks.iupui.edu/bitstream/handle/1805/344/Gliem\%20\%26\%20Gliem.pdf ? sequence $=1 \&$ is Allowed $=\mathrm{y}$

Hativa, N., Barak, R., \& Simhi, E. (2001). Exemplary University Teachers: Knowledge and Beliefs regarding Effective Teacher Dimensions and Strategies. Journal of Higher Education, 72(6), 699-729. https://doi.org/10.1080/00221546.2001.11777122

Hundarenko, O. (2019). Challenges of Teaching Academic Writing Skills in ESL Classroom (Based on International Teaching Experience). Revista Romaneasca pentru Educatie Multidimensionala, 11(4), 70-83. https://doi.org/10.18662/rrem/158

Kapranov, O. (2019). The Framing of Speech Fluency in English as a Foreign Language (EFL) by In-Service Primary School Teachers. Complutense Journal of English Studies, 27, 79-98. https://doi.org/10.5209/cjes.63613

Katooli, S., \& Abdolmanafi-Rokni, S. (2015). A Comparative Analysis of Students' and Teachers' Perceptions of Effective Foreign Language Teaching in Iran. Journal of Applied Linguistics and Language Research Volume, 2(8), 57-75. Retrieved 18 May, 2020 from http://www.jallr.com/index.php/JALLR/article/view/202/pdf202

Kourieos, S., \& Evripidou, D. (2013). Students' Perceptions of Effective EFL Teachers in University Settings in Cyprus. English Language Teaching, 6(11), 1-16. http://dx.doi.org/10.5539/elt.v6n11p1

Lee, J. (2010). The Uniqueness of EFL Teachers: Perceptions of Japanese Learners. TESOL Journal, 1(1), 23-48. https://doi.org/10.5054/tj.2010.214881

Metruk, R. (2020). Qualities of a Good and Effective Teacher: Slovak EFL Pre-Service and In-Service Teachers' Perspectives. Journal of Language and Education, 6(3), 8093. https://doi.org/10.17323/jle.2020.10593

Moradi, K., \& Sabeti, G. (2014). A Comparison of EFL Teachers and EFL Students' Understandings of 'Highly Effective Teaching'. Procedia - Social and Behavioral Sciences, 98, 1204-1213. https://doi.org/10.1016/j.sbspro.2014.03.535 
Mulyadi, D., Arifani, Y., Wijayantingsih, T., \& Budiastuti, R. (2020). Blended Learning in English for Specific Purposes (ESP) Instruction: Lecturers' Perspectives. ComputerAssisted Language Learning Electronic Journal, 21(2), 204-219.

Park, G., \& Lee, H. (2006). The Characteristics of Effective English teachers as Perceived by High School Teachers and Students in Korea. Asia Pacific Education Review, 7, 236-248. https://doi.org/10.1007/BF03031547

Ramazani, M. (2014). Mismatches in Beliefs between Teachers and Students, and Characteristics of Effective English Teacher: An Iranian Context. Procedia - Social and Behavioral Sciences, 98, 1518-1527. https://doi.org/10.1016/j.sbspro.2014.03.573

Sabbah, S. (2018). Tertiary-level Students' Perceptions of the Characteristics of Effective English as a Second Language Instructors. International Journal of English Language Teaching, 6(2), 1-24. Retrieved 18 May, 2020 from http://www.eajournals.org/wp-content/uploads/Tertiary-Level-Students\%E2\%80\%99Perceptions-of-the-Characteristics-of-Effective-English-as-a-Second-LanguageInstructors.pdf

Sandholtz, J. (2011). Pre-service Teachers' Conceptions of Effective and Ineffective Teaching Practices. Teacher Education Quarterly, 38(3), 27-47. Retrieved 18 May, 2020 from https://files.eric.ed.gov/fulltext/EJ940632.pdf

Sides, J. D., \& Cuevas, J. A. (2020). Effect of Goal Setting for Motivation, SelfEfficacy, and Performance in Elementary Mathematics. International Journal of Instruction, 13(4), 1-16. https://doi.org/10.29333/iji.2020.1341a

Shishavan, H., \& Sadeghi, K. (2009). Characteristics of an Effective English Language Teacher as Perceived by Iranian Teachers and Learners of English. English Language Teaching, 2(4), 130-143. https://doi.org/10.5539/elt.v2n4p130

Sotto, E. (2011). When Teaching Becomes Learning: A theory and Practice of Teaching (2nd ed.). London, England: Continuum Education.

Stognieva, O. (2020). Exploring the Potential of TED Talks for Teaching Business English to University Students. The Jornal of Asa TEFL, 17(4), 1468-1476 http://dx.doi.org/10.18823/asiatefl.2020.17.4.23.1468.

Štubňa, P., 2019. Simultaneous Interpretation Quality Assessment. Revista Dilemas Contemporáneos: Educación, Política y Valores 6, special issue, 1-15.

Tok, H. (2010). Comparing Teachers' and Students' Perceptions of Effective Foreign Language Teaching. A case study in Turkey. International Conference on New Trends in Education and Their Implications, 11-13 November, 2010, Antalya-Turkey, pp. 405413.

Tuncel, Z. A., \& Çobanoğlu, F. (2018). In-service Teacher Training: Problems of the Teachers as Learners. International Journal of Instruction, 11(4), 159-174. https://doi.org/10.12973/iji.2018.11411a 
Vadillio, R. (1999). Research on the good language teacher. EPOS, 15, 347-361.

Wichadee, S. (2010). Defining the Effective English Language Teacher: Students' and Teachers' Perspectives. In A. M. Stoke (Ed.) JALT2009 Conference Proceedings. Tokyo: JALT, pp. 37-35. Retrieved 18 May, 2020 from https://jaltpublications.org/archive/proceedings/2009/E033.pdf

Zadeh, R. (2016). EFL Learners' Attitudes and Perceptions about an Effective English Language Teacher. Journal of Applied Linguistics and Language Research, 3(2), 148156.

Zamani, R., \& Ahangari, S. (2015). Qualities of an Effective English Language Teacher (EELT) from Male and Female Students' Point of view. Journal of English Language Pedagogy and Practice, 8(16), 199-220. Retrieved 18 May, 2020 from http://jal.iaut.ac.ir/article_524582_6cb3273564cd974909dc701956b9b46b.pdf

\section{Appendix 1: Questionnaire}

On a scale of 1 to 4 , please, indicate the importance of the following teacher characteristics by choosing the relevant number. THERE ARE NO RIGHT OR WRONG ANSWERS, JUST THOSE THAT ARE RIGHT FOR YOU!

1 = unimportant, 2 = slightly important, $3=$ moderately important, $4=$ very important

\begin{tabular}{|c|c|c|c|c|c|}
\hline Item & A good and effective EFL teacher is someone who should: & \multicolumn{4}{|c|}{ Importance } \\
\hline 1. & Be well prepared for each lesson. & 1 & 2 & 3 & 4 \\
\hline 2. & Be able to provide clear instructions for tasks. & 1 & 2 & 3 & 4 \\
\hline 3. & Be able to present content to students in a meaningful way. & 1 & 2 & 3 & 4 \\
\hline 4. & $\begin{array}{l}\text { Personalize his/her teaching to students' lives, needs, concerns, goals, and } \\
\text { interests. }\end{array}$ & 1 & 2 & 3 & 4 \\
\hline 5. & Give a reasonable amount of homework/home assignments. & 1 & 2 & 3 & 4 \\
\hline 6. & Provide opportunities to use English through meaningful tasks and activities. & 1 & 2 & 3 & 4 \\
\hline 7. & Facilitate learners' responsibility and autonomy. & 1 & 2 & 3 & 4 \\
\hline 8. & Be up-to-date (e.g. use the Internet and recent technologies in teaching). & 1 & 2 & 3 & 4 \\
\hline 9. & Make learning fun. & 1 & 2 & 3 & 4 \\
\hline 10. & Know English culture well. & 1 & 2 & 3 & 4 \\
\hline 11. & Teach English in English - use as little L1 (mother tongue) as possible. & 1 & 2 & 3 & 4 \\
\hline 12. & Establish clear classroom rules that everyone understands and obeys. & 1 & 2 & 3 & 4 \\
\hline 13. & $\begin{array}{l}\text { Be upbeat (positive and enthusiastic; making you feel that the future will be } \\
\text { good). }\end{array}$ & 1 & 2 & 3 & 4 \\
\hline 14. & $\begin{array}{l}\text { Employ plenty of pair work and group work in which his/her learners can } \\
\text { practice English. }\end{array}$ & 1 & 2 & 3 & 4 \\
\hline 15. & $\begin{array}{l}\text { Teach how to learn English outside the classroom (teach language learning } \\
\text { strategies). }\end{array}$ & 1 & 2 & 3 & 4 \\
\hline 16. & Arouse students' motivation for learning English. & 1 & 2 & 3 & 4 \\
\hline 17. & Diagnose learners' learning problems. & 1 & 2 & 3 & 4 \\
\hline 18. & Manage the class time well and use the time efficiently. & 1 & 2 & 3 & 4 \\
\hline 19. & Be creative; use various methods and techniques in teaching. & 1 & 2 & 3 & 4 \\
\hline 20. & Teach English adapted to students' English proficiency levels. & 1 & 2 & 3 & 4 \\
\hline 21. & Actively listen to student's opinions and let them express themselves. & 1 & 2 & 3 & 4 \\
\hline 22. & Be helpful to students inside and outside the classroom. & 1 & 2 & 3 & 4 \\
\hline 23. & Support the notion that fluency is somewhat more important than accuracy. & 1 & 2 & 3 & 4 \\
\hline 24. & Help students develop self-confidence in order to learn English well. & 1 & 2 & 3 & 4 \\
\hline
\end{tabular}


25. Be fair and correct (within feedback, giving turns, attending to individual differences).

\begin{tabular}{|c|c|c|c|c|c|}
\hline 26. & Be disciplined and punctual. & 1 & 2 & 3 & 4 \\
\hline 27. & $\begin{array}{l}\text { Be knowledgeable (have the subject matter knowledge and have the } \\
\text { pedagogical knowledge). }\end{array}$ & 1 & 2 & 3 & 4 \\
\hline 28. & Be flexible. & 1 & 2 & 3 & 4 \\
\hline 29. & Be neat and tidy in appearance. & 1 & 2 & 3 & 4 \\
\hline 30. & Be available for students. & 1 & 2 & 3 & 4 \\
\hline 31. & Be open to constructive criticism. & 1 & 2 & 3 & 4 \\
\hline 32. & $\begin{array}{l}\text { Show interest in students (e.g. by remembering their names, etc.) and their } \\
\text { learning. }\end{array}$ & 1 & 2 & 3 & 4 \\
\hline 33. & Have good communication skills. & 1 & 2 & 3 & 4 \\
\hline 34. & Have a high level of English proficiency. & 1 & 2 & 3 & 4 \\
\hline 35. & Be patient (allow for students' questions, comments, and participation). & 1 & 2 & 3 & 4 \\
\hline 36. & $\begin{array}{l}\text { Build a positive relationship with students but focus on retaining a professional } \\
\text { distance. }\end{array}$ & 1 & 2 & 3 & 4 \\
\hline 37. & Be polite and respect the personality of students. & 1 & 2 & 3 & 4 \\
\hline 38. & Not lose temper and get angry. & 1 & 2 & 3 & 4 \\
\hline 39. & Establish a relaxed atmosphere in the classroom. & 1 & 2 & 3 & 4 \\
\hline 40. & Monitor progress and provide learners with useful and constructive feedback. & 1 & 2 & 3 & 4 \\
\hline 41. & Have a university degree in Teaching English as a Foreign Language. & 1 & 2 & 3 & 4 \\
\hline 42. & Have more than five years' experience of English teaching. & 1 & 2 & 3 & 4 \\
\hline 43. & Be familiar with the social and cultural background of learners. & 1 & 2 & 3 & 4 \\
\hline 44. & Be aware of the current teaching techniques. & 1 & 2 & 3 & 4 \\
\hline 45. & Know how to assess learners' performance reasonably, correctly, and fairly. & 1 & 2 & 3 & 4 \\
\hline 46. & $\begin{array}{l}\text { Regard errors as an inseparable part of the learning process; self-correction is } \\
\text { encouraged. }\end{array}$ & 1 & 2 & 3 & 4 \\
\hline 47. & Have good and effective classroom management skills. & 1 & 2 & 3 & 4 \\
\hline 48. & $\begin{array}{l}\text { Vary class interaction strategies (e.g. use group and pair work, drama, role- } \\
\text { plays, debates, etc.). }\end{array}$ & 1 & 2 & 3 & 4 \\
\hline 49. & Be able to assess learners' strengths and weaknesses. & 1 & 2 & 3 & 4 \\
\hline 50. & Speak audibly and clearly. & 1 & 2 & 3 & 4 \\
\hline 51. & Be able to explain unfamiliar concepts in various ways. & 1 & 2 & 3 & 4 \\
\hline 52. & Come to class on time and finish on time. & 1 & 2 & 3 & 4 \\
\hline 53. & Be able to cooperate with colleagues to improve the current teaching practices. & 1 & 2 & 3 & 4 \\
\hline 54. & Be confident and have self-control. & 1 & 2 & 3 & 4 \\
\hline 55. & Have a positive attitude towards change and innovation. & 1 & 2 & 3 & 4 \\
\hline 56. & $\begin{array}{l}\text { Participate in teacher professional growth events such as seminars, workshops, } \\
\text { conferences, etc. in order to develop professionally. }\end{array}$ & 1 & 2 & 3 & 4 \\
\hline 57. & Be ready to learn new methods and teaching strategies. & 1 & 2 & 3 & 4 \\
\hline
\end{tabular}

